\title{
Inteligencja katolicka a kultura narodowa. Refleksja na kanwie Centesimus annus
}

W rozważaniach nad przesłaniem encykliki Centesimus annus zagadnienie znaczenia inteligencji katolickiej dla życia narodu może się wydawać niewarte uwagi. Jednak to na tej bardzo specyficznej kategorii społecznej spoczywa obowiązek, który stanowi ważny element przesłania papieskiego zawartego w encyklice opublikowanej w setną rocznicę $R e$ rum novarum. Papieski dokument objaśnia wiernym, że demokratyczny system polityczny i wolnorynkowa gospodarka tworzą świat zagrożeń i możliwości, w którym chrześcijanin, inspirując się Ewangelią oraz działając w sposób aktywny i twórczy, może pomnażać otrzymane od Boga talenty, a także realizować swoje powołanie w imię miłości, solidarności i pracy dla rozwoju dobra wspólnego ${ }^{1}$. Jednocześnie jednak Jan Paweł II przestrzega przed przyjmowaniem popularnego współcześnie poglądu, że to agnostycyzm i sceptyczny relatywizm są adekwatną postawą dla demokratycznych form polityki, że to większość decyduje o prawdzie lub że prawda zależy od politycznej równowagi sił. Ten rodzaj poglądów może w demokracji, prędzej czy później, doprowadzić społeczeństwo do zguby - do jawnego lub zakamuflowanego totalitaryzmu².

Papież wskazuje więc wyraźnie, że system demokratyczny wymaga przyjęcia zobowiązania do wychowania i formowania obywateli w duchu prawdziwych ideałów, państwo powinno dbać o podmiotowość społeczeństwa przez tworzenie struktur uczestnictwa oraz współodpowiedzialności ${ }^{3}$.

1 Zob. M. Zięba, Jestem z Wami. Kompendium twórczości i nauczania Karola Wojtyły Jana Pawła II, Kraków 2010, s. 95-99.

${ }^{2}$ CA 46.

3 Tamże. 
Innymi słowy, dla rozwoju demokracji niezbędny jest odpowiedni, obywatelski i wspólnotowy etos, oparty na prawdzie i wolności, a zakorzeniony w Bogu i kulturze narodowej.

Jak potrzebny jest to etos, pokazuje polska historia i znaczenie warstwy inteligenckiej dla utrzymania kultury narodowej i odzyskania przez polski naród państwowości. Pokazuje to przykład pokoleń polskich inteligentów, które tożsamościowo dojrzewały w cieniu wciąż obecnej specjalnej misji narodowej. Inteligencja w Polsce, odgrywająca od xIx wieku ogromną rolę w strukturze polskiego społeczeństwa, była w stanie stale reprodukować swój status społeczny za pomocą kapitału kulturowego (rozumianego jako wykształcenie, wychowanie, ale także etos, wiara, wartości etc.). W miejscu targanym raz po raz konfliktami zbrojnymi i radykalnymi zmianami politycznymi kapitał kulturowy był jedynym zasobem w naszej części Europy, który pozwalał się w miarę stabilnie akumulować, a potem przekazywać. Duże znaczenie w tej walce o prawo do kultury narodowej, a później prawo do własnej państwowości odegrała warstwa „dobrze wykształconych”, przy znaczącym udziale ludzi Kościoła, tj. przedstawicieli polskiej inteligencji katolickiej i ich szczególnego etosu zobowiązującego do zaangażowania społecznego.

Celem niniejszego artykułu jest próba rekonstrukcji etosu inteligencji katolickiej w świetle encykliki Centesimus annus i na polskim przykładzie ukazanie, jak duże znaczenie ma wspomniana kategoria społeczna i jej etos dla utrzymania i rozwoju kultury narodowej.

\section{Casus polskiej inteligencji}

Zniknięcie w XVIII wieku Rzeczypospolitej Polskiej z map świata zapoczątkowało silne zmiany strukturalne polskiego społeczeństwa. Wraz z upadkiem państwowości naród polski systematycznie zaczął tracić także kapitał ekonomiczny. Począwszy od osiemnastowiecznych rozbiorów, przez cały wiek XIX postępował zarówno schyłek bogatego ziemiaństwa, jak i regres polskich miast, odciętych od europejskiej modernizacji i większych inwestycji, tłamszący rodzącą się dopiero burżuazję - następowało systematyczne zmniejszanie się znaczenia polskich elit ekonomicznych. Uwłaszczenie ziem pod zaborami oraz powstańcze zrywy (i kary za nie w postaci np. uwłaszczenia bez odszkodowań, jak zarządzono w zaborze rosyjskim po powstaniu styczniowym), dodatkowo 
uderzały w elity gospodarcze i posiadane przez nie zasoby materialne. Kryzys gospodarki folwarcznej, wojna, a przede wszystkim rewolucja bolszewicka i nacjonalizacja mienia, ale także tzw. pokój ryski z 1921 roku, na mocy którego polskie państwo zrzekało się w stosunku do dawnych kresów zarówno roszczeń politycznych, jak i własnościowych, pozostawiając na tych terenach znaczną część zasobów polskiego ziemiaństwa, wpłynęły na kształt systemu gospodarczego II Rzeczpospolitej i liczne problemy ekonomiczne, z którymi borykała się ówczesna władza, zwielokrotnione Wielkim Kryzysem lat 30. i odcięciem relacji gospodarczych z komunistyczną Rosją ${ }^{4}$.

Temu spadkowi znaczenia elit ekonomicznych towarzyszył jednocześnie wyraźny wzrost siły inteligencji (jako kategorii społecznej), która między upadkiem powstania styczniowego a odzyskaniem polskiej państwowości w 1918 roku - jak pisze Magdalena Micińska - przeżywa okres wyjątkowego intelektualnego ożywienia, wyznaczając sobie „bodaj najwyższe w swej historii aspiracje" i ciesząc się nieznanym dotąd prestiżem ${ }^{5}$ Później II Rzeczpospolita, nazwana przez Tomasza Zaryckiego i Tomasza Warczoka "republiką inteligencką"6, za kluczowe wartości obywatelskie uznaje wzorce charakterystyczne dla etosu postszlacheckiej inteligencji, zaś za głównych bohaterów narodowych ma inteligentów, ofiary dziewiętnastowiecznych powstań. Nowo powstała Polska, słaba gospodarczo, tworzy silne i rozbudowane instytucje, które funkcjonują dzięki dobrze wykształconym i rozumiejącym etos służby publicznej inteligentom. Powstają i rozwijają się uczelnie wyższe i elitarne gimnazja, z których wiele przetrwało nie tylko II wojnę światową, ale także PRL. Tej kontynuacji nie udało się osiągnąć w sektorze gospodarczym - takiego okresu nie przetrwała właściwie żadna polska firma. Trudna historia polskiego narodu umożliwiała pokoleniową reprodukcję właściwie tylko jednego kapitału - kulturowego. Od samego powstania inteligencji, tej wyjątkowej warstwy społecznej, nałożone było na nią silne zobowiązanie. To dzięki twórcom kultury i warstwie upowszechniającej ich

4 Zob. T. Zarycki, T. Warczok, Hegemonia inteligencka. Kapitał kulturowy we wspótczesnym polskim polu władzy. Perspektywa „długiego trwania”, „Kultura i Społeczeństwo” (2014), $\mathrm{nr}$ 4, s. 31-33.

M. Micińska, Inteligencja na rozdrożach 1864-1918, w: Dzieje inteligencji polskiej do roku 1918, t. 3, red. J. Jedlicki, Warszawa 2008, s. 11.

6 T. Zarycki, T. Warczok, Hegemonia inteligencka..., s. 31. 
wytwory polską kulturę udało się zachować, mimo przeszło studwudziestoletniego starcia $\mathrm{z}$ trzema, często lepiej rozwiniętymi, kulturami zaborców. Wykształceni i zaangażowani w życie społeczne i publiczne Polacy z wszystkich trzech zaborów mieli znaczący udział w niesieniu patriotycznych treści, budowaniu wspólnej tożsamości, a później w scalaniu kulturowym i instytucjonalnym polskiego państwa $\mathrm{z}$ różnorodnych kulturowo ziem odzyskanych po zaborcach.

Wbrew oczekiwaniom inteligencja w II RP nie zaczęła pełnić $\mathrm{w}$ debacie publicznej roli przywódczej, nie stanęła na czele politycznych ruchów, szybko zrażając się do polityki w wersji demokratycznej - stąd wraz z odzyskaniem niepodległości coraz powszechniej zaczęto mówić o kryzysie polskiej inteligencji ${ }^{7}$. Na podatny grunt padła jednak idea propaństwowości - misja służby publicznej w warunkach odzyskanego państwa pojawiła się wśród inteligencji bardzo wcześnie i zbudowała etos osób wykształconych odbudowujących w codziennym trudzie polskie państwo. Choć istnieli liderzy opinii, to ich autorytet w dużej mierze ograniczony był do wąskiego pola kultury i nie przekładał się na perspektywę ogólnokrajową. W tym sensie rola intelektualistów jako krytyków otaczającej rzeczywistości (głównie politycznej) obecna była w ledwie umiarkowanym stopniu. Odzyskanie niepodległości wskazywało też na inne priorytety - odbudowę państwa, a nie walkę z nim. Już od wczesnych lat 20. polska publicystyka inteligencka wyraźnie stawiała priorytety, kładąc nacisk na ochronę kultury, pracę umysłową i wspieranie budowy państwa ${ }^{8}$. To zresztą charakterystyczne dla polskiej inteligencji lat międzywojennych - niechęć do polityki (a zwłaszcza partii politycznych), ale afirmacja instytucji państwowych ${ }^{9}$.

Trzy elementy określające świadomość społeczną czasów zaborów zdają się doskonale pasować do polskiego społeczeństwa także sto lat później. Po II wojnie światowej, choć warstwa inteligencji została silnie przetrzebiona przez wojnę i zbrodnicze działania okupantów, potrzeba powrotu do etosu inteligencji dziewiętnastowiecznej szybko pojawiła

7 Zob. M. Gawin, Abdykacje i restauracje. Debaty o zmierzchu inteligencji polskiej $w$ latach międzywojennych i współcześnie, w: Inteligencja w Polsce. Specjaliści, twórcy, klerkowie, klasa średnia?, red. H. Domański, Warszawa 2008, s. 241-250.

8 Tamże, s. 245-247.

9 Tamże, s. 246, 260. 
się ponownie. Podobna była społeczna ocena sytuacji, w której tkwiło polskie społeczeństwo - zniuansowany, ale głęboki sprzeciw wobec zastanej rzeczywistości. Dalej, podobnie przedstawiały się nastroje społeczne oparte przede wszystkim na poczuciu i świadomości własnej bezsilności, na apatii i rozgoryczeniu. I w końcu obraz dopełniał brak swobody działania i wyrażania myśli, niemożność pełnej manifestacji poglądów na rzeczywistość. Wówczas jednak stosunek do państwa (a dokładnie państwa socjalistycznego) był najczęściej negatywny, jednocześnie wszelkie działania w walce o autonomię wiary, myśli, nauki czy kultury miały wydźwięk polityczny, bo kwestionowały zwierzchnią rolę partii i jej propagandową linię.

I w takich właśnie warunkach umiejscowić można wiele opowieści o naukowcach poświęcających się tajnemu projektowi edukacji, często także edukacji chrześcijańskiej, przedstawicielach nonkonformistycznej inteligencji, podejmującej działania w podziemiu, czy zaangażowanych i aktywnych społecznie księżach oraz działaczach katolickich. Dla polskiego inteligenta-społecznika tamtych czasów charakterystyczna była postawa niepokorności w połączeniu ze służbą i z odpowiedzialnością za innych. Taki model inteligenta oparty był na poświęceniu, na nakazie edukacyjnym ukierunkowanym nie na siebie, ale wobec innych. Takie postawy tworzyły etos polskiej inteligencji (także, a może przede wszystkim, katolickiej), który w sposób szczególny wpływał na utrzymanie kultury narodowej w niesprzyjających dla niej czasach.

\section{Etos inteligencji katolickiej a kultura narodu}

Nie bez powodu Jan Paweł II w tekście encykliki, poruszając przede wszystkim problemy dotyczące dynamiki w ramach wielkich struktur społecznych (rozpadu bloku państw komunistycznych, rozszerzającego się świata demokracji liberalnej i systemu kapitalistycznego), stale podkreśla płaszczyznę mikro, przypominając tym samym o miejscu człowieka w złożonym świecie politycznych, gospodarczych i instytucjonalnych powiązań. Miejscu wskazującym zarówno na indywidualny, jak i wspólnotowy charakter społecznego funkcjonowania człowieka, wyrażony przez dwa jego atrybuty, które w encyklice wymieniane są obok siebie kilkakrotnie, inteligencję i wolność: „Człowiek urzeczywistnia siebie samego poprzez swoją inteligencję i swoją wolność, i dokonując tego, traktuje 
jako przedmiot i narzędzie rzeczy tego świata i sobie je przywłaszcza. W działaniu tym tkwi podstawa prawa do inicjatywy i do własności indywidualnej. Poprzez swoją pracę człowiek angażuje się nie tylko dla samego siebie, ale także dla drugich i z drugimi: każdy współdziałając uczestniczy w pracy i dobru drugiego" ${ }^{\prime 10}$.

Oba atrybuty konstytuują człowieka w życiu społecznym: predestynują go do pracy ${ }^{11}$, pozwalają wykorzystać możliwości produkcyjne ziemi i aktywnie odpowiadać na powstające potrzeby człowieka ${ }^{12}$; to jednocześnie dwie niezbędne cechy osoby ludzkiej, które umożliwiają służbę prawdzie, a więc i służbę Bogu. Pozwalają żyć wolnością, ofiarowując prawdę - chrześcijanin swoimi działaniami ma potwierdzać to, co „poznał dzięki wierze i właściwemu używaniu rozumu"'13, bo każdy człowiek w swej naturze jest poszukiwaczem prawdy. To poszukiwanie powraca i odnawia się w każdym pokoleniu, co charakterystyczne jest dla każdej kultury narodowej. Jednocześnie Jan Paweł il wskazuje wyraźnie, że rdzeniem każdej tego typu kultury jest postawa człowieka wobec tajemnicy najdonioślejszej i najgłębszej: tajemnicy Boga. Każdy naród poprzez swoją kulturę na swój własny sposób odpowiada na pytanie o sens osobistej egzystencji, gdy jednak w wyniku coraz większej skali indyferencji - tak charakterystycznej dla współczesnej cywilizacji to najważniejsze pytanie jest uchylone, a odpowiedzi zakwestionowane, to cała kultura i życie moralne narodu, zdaniem papieża, ulegają rozkładowi ${ }^{14}$.

Jan Paweł II jest przekonany, że Kościół rozwija właściwości ludzkich postaw, które sprzyjają kulturze pokoju, inicjatywie i wolności ${ }^{15}$. Wielokrotnie dawał też wyraz przekonaniu, jak ważna w życiu człowieka i społeczeństwa jest posługa myślenia, czyli po prostu służba prawdzie w wymiarze społecznym. Jego zdaniem każdy intelektualista (jako przedstawiciel elity inteligencji) powołany jest do tego, by pełnił funkcję sumienia, krytycznego wobec wszystkich poglądów, postaw i zjawisk,

\footnotetext{
10 CA 43.

11 CA 31.

12 CA 32.

${ }^{13} \mathrm{CA} 46$.

14 CA 24.

15 Tamże.
} 
które człowieczeństwu zagrażają ${ }^{16}$. „Szczególne zadanie mają do spełnienia intelektualiści katoliccy - pisał Ojciec święty w Evangelium vitae powołani do aktywnej obecności w środowiskach kulturotwórczych, w szkołach i uniwersytetach, w ośrodkach badań naukowych i technicznych, na polu twórczości artystycznej i refleksji humanistycznej. Czerpiąc energię dla myśli i działania z czystych wód Ewangelii, winni angażować się w służbę na rzecz nowej kultury życia poprzez swoje dokonania - poważne i udokumentowane, zasługujące na szacunek i zainteresowanie wszystkich"17.

Inteligencja katolicka ma więc szczególną rolę w doskonaleniu świata, powinna wyrabiać myśl, tworzyć kulturę w narodzie, działać w służbie życia ludzkiego, w służbie prawdy. W 1987 roku w murach Katolickiego Uniwersytetu Lubelskiego Jan Paweł II podkreślał, jak bardzo nieoceniona jest rola tej uczelni jako wychowawcy inteligencji katolickiej w Polsce w duchu wartości chrześcijańskich, humanistycznych i narodowych: „Uniwersytet Lubelski powstał i istnieje pod hasłem Deo et Patriae. Słowa te mówią o służbie. O służbie Bogu i Kościołowi oraz Narodowi i Ojczyźnie. [...] Miłość prawdy w służbie człowieka. Kształtowanie świadomości i postawy narodowej poprzez rzetelną służbę prawdzie"18. Już kilka lat wcześniej, w 1979 roku, w przemówieniu do profesorów i studentów KUL podkreślał, że z samej nazwy „uniwersytet” nic jeszcze nie wynika dla sprawy człowieka i że nie o samo wykształcenie chodzi w nauczaniu. Działalność uniwersytecka to jeden z niezwykle ważnych odcinków walki o „człowieczeństwo człowieka”, a pytaniem podstawowym, które należy postawić w świecie akademickim, zwłaszcza na katolickim uniwersytecie, jest to, czy udało się wyzwolić „ten olbrzymi potencjał duchowy człowieka, przez który człowiek urzeczywistnia swoje człowieczeństwo. To jest decydujące"19.

Idea kształcenia inteligencji katolickiej była podstawowym powodem tworzenia przez Kościół uczelni wyższych. Zakładano bowiem, że ludzie

${ }^{16}$ Zob. Jan Paweł II, Przemówienie z okazji 6oo-lecia Wydziału Teologicznego Uniwersytetu Jagiellońskiego z 8 VI 1997, 5, www.nauczaniejp2.pl (17.03.2015).

${ }^{17} \mathrm{EV} 98$.

${ }^{18}$ Jan Paweł II, Homilia $w$ czasie liturgii słowa skierowana do środowiska Katolickiego Uniwersytetu Lubelskiego z 9 vi 1987, 7, www.nauczaniejp2.pl (17.03.2015).

${ }_{19}$ Tenże, Przemówienie do profesorów i studentów Katolickiego Uniwersytetu Lubelskiego z 6 vi 1979, www.nauczaniejp2.pl (17.03.2015). 
dobrze wykształceni oraz ugruntowani religijnie i moralnie to ludzie przygotowani do budowania ładu społecznego. Nic więc dziwnego, że w czasach PRL władza próbowała zepchnąć inteligencję katolicką na margines, wyrzucić na społeczne obrzeża, ograniczyć im społeczną działalność. Rozrost socjalistycznego państwa, które kontroluje wszystkie dziedziny życia społecznego, zawłaszcza wszelkie inicjatywy dla siebie i tłumi jakąkolwiek oddolną inicjatywę społeczną, doprowadził do kryzysu tożsamości i hermetyzacji społecznej tej części inteligencji, która wciąż żyła przedwojenną Polską. Następowała także „produkcja” nowej inteligencji. W odróżnieniu od procesu samorzutnego kształtowania się tej warstwy w XIX i w pierwszej połowie xx wieku, tym razem partia zaplanowała formowanie się tej kategorii społecznej. Inteligent, wedle celów wyznaczonych przez władzę ludową, miał przekształcić się w fachowca, co nawet przychylny ówczesnej władzy Józef Chałasiński nazwał "proletaryzacją zawodów inteligenckich" ${ }^{20}$.

Czas PRL to ponowne odwołanie się w środowiskach opozycyjnych do etosu dziewiętnastowiecznej inteligencji zaangażowanej, próba budowania na nowo tożsamości tej kategorii społecznej - w oparciu o mit niepokorności i rolę dialogu, wolności, ale także z wyraźnie uwypukloną wrażliwością społeczną. Był to czas, w którym właściwie jedyną realną przestrzenią wolnej myśli był Kościół katolicki, przyciągający wówczas wielu twórców o lewicowych poglądach, rozczarowanych istniejącymi wokół wypaczeniami socjalizmu. Zwrócił na to uwagę także Jan Paweł II w jednym z przemówień w 1987 roku: „Raduję się, że intelektualiści, artyści, ludzie kultury znajdują w Kościele przestrzeń wolności, której nieraz brakuje im gdzie indziej. I że dzięki temu odkrywają istotę i rzeczywistość duchową Kościoła, którą przedtem widzieli jakby z zewnątrz" ${ }^{21}$.

Encyklika Centesimus annus to głos papieski apelujący o zaistnienie w przestrzeni demokratycznej postawy pielęgnującej wolność i inteligencje jako poszukiwanie Boga i prawdy. To wyrażone nie wprost wskazanie na charakterystyczny etos, którym powinien cechować się każdy dobrze wykształcony katolik, budujący w relacji z drugim człowiekiem siłę narodowej kultury: „Rzeczywiste kształtowanie się kultury wymaga

\footnotetext{
${ }^{20}$ J. Chałasiński, Przeszłość i przyszłość inteligencji polskiej, Warszawa 1997, s. 18.

${ }^{21}$ Jan Paweł II, Przemówienie do przedstawicieli świata kultury zgromadzonych $w$ kościele Świętego Krzyża z 13 VI 1987, 7, www.nauczaniejp2.pl (17.03.2015).
} 
włączenia się całego człowieka, który wyraża w niej swój zmysł twórczy, inteligencję, znajomość świata i ludzi. Angażuje w nią także swoją umiejętność panowania nad sobą, osobistego poświęcenia, solidarności i pracy dla rozwoju dobra wspólnego" ${ }^{22}$.

Wszystko, co najistotniejsze dla etosu inteligencji katolickiej, Ojciec święty wyraził podczas niezwykle ważnego przemówienia na dziedzińcu KUL w 1987 roku, uwypuklając najważniejsze komponenty postawy „dobrze wykształconego katolika”: „Służ Prawdzie! Jeśli służysz Prawdzie służysz Wolności. Wyzwalaniu człowieka i Narodu. Służysz Życiu!”23. Ten apel każdy przedstawiciel inteligencji katolickiej mógłby potraktować jako apel skierowany do niego osobiście.

\section{Bibliografia}

Chałasiński J., Przeszłość i przyszłość inteligencji polskiej, Świat Książki, Warszawa 1997.

Gawin M., Abdykacje i restauracje. Debaty o zmierzchu inteligencji polskiej w latach międzywojennych i współcześnie, w: Inteligencja w Polsce. Specjaliści, twórcy, klerkowie, klasa średnia?, red. H. Domański, IFiS pan, Warszawa 2008, s. 241-262.

Jan Paweł II, Encyklika Centesimus annus, przedruk: Libreria Editrice Vaticana, Włocławek 1991.

Jan Paweł II, Encyklika Evangelium vitae, Libreria Editrice Vaticana, Watykan 1995.

Jan Paweł II, Homilia w czasie liturgii słowa skierowana do środowiska Katolickiego Uniwersytetu Lubelskiego z 9 vi 1987, http://www.nauczaniejp2.pl/ dokumenty/wyswietl/id/734 (17.03.2015).

Jan Paweł II, Przemówienie do profesorów i studentów Katolickiego Uniwersytetu Lubelskiego z 6 vi 1979, http://www.nauczaniejp2.pl/dokumenty/wyswietl/ $\mathrm{id} / 625$ (17.03.2015).

Jan Paweł II, Przemówienie do przedstawicieli świata kultury zgromadzonych w kościele Świętego Krzyża z 13 vi 1987, http://www.nauczaniejp2.pl/dokumenty/wyswietl/id/811 (17.03.2015).

\footnotetext{
${ }^{22}$ CA 51.

${ }^{23}$ Jan Paweł II, Homilia w czasie liturgii słowa skierowana do środowiska Katolickiego Uniwersytetu Lubelskiego z 9 vi 1987, 9.
} 
Jan Paweł II, Przemówienie z okazji 6oo-lecia Wydziału Teologicznego Uniwersytetu Jagiellońskiego z 8 VI 1997, http://www.nauczaniejp2.pl/dokumenty/ wyswietl/id/451 (17.03.2015).

Micińska M., Inteligencja na rozdrożach 1864-1918, w: Dzieje inteligencji polskiej do roku 1918, t. 3, red. J. Jedlicki, IFIS PAN, Warszawa 2008.

Zarycki T., Warczok T., Hegemonia inteligencka. Kapitał kulturowy we współczesnym polskim polu władzy. Perspektywa „długiego trwania”, „Kultura i Społeczeństwo" (2014), $\mathrm{nr}$ 4, s. 27-49.

Zięba M., Jestem z Wami. Kompendium twórczości i nauczania Karola Wojtyły Jana Pawła II, Wydawnictwo M, Kraków 2010.

\title{
Abstrakt
}

Artykuł jest próbą rekonstrukcji etosu inteligencji katolickiej w świetle encykliki Centesimus annus i ukazania na przykładzie polskiej inteligencji, jak duże znaczenie ma ta kategoria społeczna i jej etos dla utrzymania i rozwoju kultury narodowej. Wspomniany etos - zgodnie z nauczeniem Jana Pawła II - opiera się na pięciu elementach, złączonych przesłaniem Ewangelii: inteligencji, wolności, prawdzie, kulturze narodowej i życiu człowieka.

Catholic intelligentsia and national culture. Reflection on canvas Centesimus annus

\begin{abstract}
This article is attempt to reconstruct the ethos of Catholic intelligentsia in the light of Centesimus annus. It shows how important is this social category and its ethos for the maintenance and development of national culture. That ethos according to the teaching of John Paul II - based on five elements united by message of the Gospel: intelligence, freedom, truth, national culture and human life.
\end{abstract}

